\title{
Relevance of Helicobacter pylori virulence factors for vaccine development
}

\author{
Luz del Carmen Hernández-Hernández, MS,(1) Eduardo César Lazcano-Ponce, PhD, (2) \\ Yolanda López-Vidal, PhD, ${ }^{(3)}$ Germán Rubén Aguilar-Gutiérrez, PhD ${ }^{(1)}$
}

\begin{abstract}
Hernández-Hernández LC, Lazcano-Ponce EC, López-Vidal Y,Aguilar-Gutiérrez GR. Relevance of Helicobacter pylori virulence factors for vaccine development.

Salud Publica Mex 2009;5 I suppl 3:S447-S454.
\end{abstract}

\begin{abstract}
Helicobacter pylori infection increases the risk for a wide spectrum of clinical outcomes, ranging from peptic ulcer disease to gastric cancer. However, the infection induces gastric and duodenal ulceration or gastric cancer in only a minority of infected subjects because $H$. pylori strains are genetically diverse and express different virulence factors. Individuals infected with strains that express these virulence factors probably develop severe diseases such as gastric cancer. Nevertheless, the ancient relationship between $H$. pylori and humans suggests that some strains could be beneficial to human health, which means that generalized administration of antibiotic therapy could eventually cause problems. The development of vaccines based on virulence factors that provide long-term protection is the best strategy for control and/or elimination of pathogenic strains. The different immunization schemes and formulations designed to evaluate the vaccines based on virulence factors in animal models have offered promising results. However, it is necessary to determine whether or not these results can be reproduced in humans. This article reviews recent vaccination studies that explore this possibility: oral vaccines using urease or inactivated whole cells plus LT as adjuvant and urease expressed in Salmonella spp. vectors, as well as a parenteral multicomponent vaccine plus aluminum hydroxide as adjuvant. Although these studies have achieved limited success, they have established support for the development of an effective vaccine against this infection.
\end{abstract}

Key words: Helicobacter pylori; virulence factors; gastric cancer; vaccines
Hernández-Hernández LC, Lazcano-Ponce EC,

López-VidalY,Aguilar-Gutiérrez GR.

Relevancia de los factores de virulencia

de Helicobacter pylori para el desarrollo de vacunas.

Salud Publica Mex 2009;5 I supl 3:S447-S454.

\section{Resumen}

La infección por Helicobacter pylori incrementa el riesgo de un amplio espectro de cuadros clínicos, que van de la úlcera péptica al cáncer gástrico. Sin embargo, la infección sólo induce ulceración gástrica y duodenal o cáncer gástrico en la minoría de los sujetos infectados debido que las cepas de $H$. pylori son genéticamente diversas y expresan diferentes factores de virulencia.Así, los individuos infectados por cepas que expresan estos factores de virulencia probablemente desarrollan enfermedades severas como el cáncer gástrico. Sin embargo, la ancestral relación entre $H$. pylori y los humanos sugiere que algunas cepas pueden ser beneficiosas para la salud humana. Por lo tanto, la administración generalizada de tratamientos con antibiótico podría eventualmente causar problemas. El desarrollo de vacunas con base en factores de virulencia que confieran protección a largo plazo es la mejor estrategia para el control y/o eliminación de cepas patógenas. Los diferentes esquemas y formulaciones de inmunización diseñados para evaluar las vacunas con base en factores de virulencia en modelos animales han dado resultados prometedores. Sin embargo, ha sido necesario probar si estos resultados pueden ser reproducidos en humanos. Este trabajo revisa los recientes estudios de vacunación que han explorado esta posibilidad: vacunas orales usando ureasa - células completas-inactivadas con LT como adyuvante y ureasa expresada en vectores de Salmonella spp.; además de una vacuna intramuscular multicomponente con hidróxido de aluminio como adyuvante.Aunque estos estudios han logrado limitado éxito han establecido las bases para el desarrollo de una vacuna eficaz contra esta infección.

Palabras clave: Helicobacter pylori; factores de virulencia;cáncer gástrico; vacunas

(I) Centro de Investigación sobre Enfermedades Infecciosas, Instituto Nacional de Salud Pública. Cuernavaca, Morelos, México.

(2) Centro de Investigación en Salud Poblacional, Instituto Nacional de Salud Pública. Cuernavaca, Morelos, México.

(3) Facultad de Medicina, Universidad Nacional Autónoma de México. México DF, México.

Received on: July 28, 2008 - Accepted on: January 19, 2009

Address reprint requests to: Dr. Germán Rubén Aguilar Gutiérrez. Dirección de Área de Enfermedades Crónicas y Cáncer,

Centro de Investigación sobre Enfermedades Infecciosas, Instituto Nacional de Salud Pública.

Av. Universidad 655, col. Santa María Ahuacatitlán. 62100, Cuernavaca, Morelos, México.

E-mail: graguila@insp.mx 
H elicobacter pylori is a gram-negative and microaerofilic bacterium that was isolated for the first time by Marshall and Warren in 1983 after extended incubation of pure culture from a human gastric mucosa biopsy. ${ }^{1,2}$ This discovery and subsequent studies radically changed existing knowledge of gastroenterology and medical microbiology. As a result of this important contribution to biological science, these Australian researchers were awarded the Nobel Prize in Physiology or Medicine in 2005.

\section{Epidemiology}

H. pylori infection constitutes an important worldwide public health problem because it is estimated that $50 \%$ of the human population is chronically infected by this pathogen. The prevalence of the infection can vary widely between and within population groups and is attributed to different socioeconomic conditions as well as basic sanitation. In fact, there is an inverse relationship between prevalence and socioeconomic conditions. ${ }^{3}$ The mode of transmission from the stomach of one person to another has not yet been clearly identified. The most widely accepted hypothesis suggests direct person to person contact since prevalence of the infection is high among individuals living in institutions and families living in overcrowded conditions. ${ }^{4,5}$ The most probable route of transmission is oral-oral because $H$. pylori DNA can be detected in vomitus, saliva, dental plaque and gastric juice. ${ }^{6}$ The fecal-oral route is another proposed means of transmission, based on the cultures of $H$. pylori from the faeces of children and adults with dyspepsia and the identification of $H$. pylori and enteropathogenic bacteria in water sources for human consumption. ${ }^{7-9}$

\section{Associations between $H$. pylori infection and different clinical manifestations}

The chronic presence of $H$. pylori in gastric mucosa activates the inflammatory response by stimulating the production of cytokines by the epithelial cells. ${ }^{10}$ This inflammation generates an active chronic gastritis that can progress to gastric atrophy, metaplasia and dysplasia, conditions associated with the development of lymphoma and gastric adenocarcinoma. ${ }^{11,12}$ Although spontaneous clearance of the infection is uncommon, most individuals infected with $H$. pylori are asymptomatic. The percentage of people developing serious illnesses such as peptic ulcer disease is 15 to $20 \%$, and less than $1 \%$ develops gastric adenocarcinoma. It is not clear whether the natural history of $H$. pylori evolves differently in different parts of the world. Nevertheless, there is now much evidence that this organism has been part of normal human microbiota since time immemorial and that it has been evolving, which suggests that the elimination of $H$. pylori may have risks as well as benefits for human health. Eradication of $H$. pylori may remove some beneficial bacterial strains and may provoke esophageal disease or gastric cancer at the cardia. ${ }^{13}$

\section{H. pylori virulence factors}

The availability of three independent sequences of the $H$. pylori genome has allowed for rapid advance in knowledge about the bacterium's mechanisms of virulence, which has increased our understanding of the molecular genetic basis for the pathogenesis of $H$. pylori ${ }^{14}$ Certain $H$. pylori strains are associated with different virulence factors that contribute in dissimilar ways to gastric mucosal damage; among them are factors known to be required for the colonization and survival of $H$. pylori in the human stomach. ${ }^{15}$ To date, scientists have identified several $H$. pylori virulence factors that confer protection against $H$. pylori infection or assist in eradicating an already established infection in the murine models. For these reasons, different virulence factors of $H$. pylori are being used for the development of an effective human vaccine against this infection. ${ }^{16}$

\section{Urease}

Urease is a multimeric complex made up of six protein subunits of UreA and six of UreB, with two nickel ions in each UreB subunit. H. pylori produces a large amount of this enzyme to catalyze the hydrolysis of the urea in ammonium and carbon dioxide; the ammonium produced neutralizes the $\mathrm{pH}$ of the area surrounding the microorganism, allowing it to evade the bactericidal properties of the hydrochloric acid of the stomach and to initiate the process of gastric mucosal colonization. ${ }^{17}$ Mutant strains of $H$. pylori negative for this enzyme are incapable of infecting the gastric epithelium of mice. ${ }^{18}$ For this reason, and because it is a protein that is widely conserved among the various strains of $H$. pylori, urease has been used as an antigenic component of potential vaccines in human tests.

\section{Vacuolating cytotoxin (VacA)}

$\operatorname{Vac} A$ is another virulence factor that is actively secreted into the adjacent tissue where it produces gastric epithelial damage. ${ }^{19}$ The vacA gene is present in all $H$. pylori strains, but the active toxin is produced by $50 \%$ isolated bacteria from clinical cases and is epidemiologically associated with various gastroduodenal diseases. ${ }^{20}$ In 
vitro, this toxin induces the alteration of vesicular traffic in eukaryote cells after being activated through exposure to acid or alkaline $\mathrm{pH}$, which leads to the formation of large vacuoles containing late endosomal and lysosomal markers that cause cellular damage. ${ }^{21}$ It also inhibits the stimulation of T-lymphocytes, interfering with the processing of specific peptides in the antigen-presenting cells, which is an important part of $H$. pylori's survival strategy and contributes significantly to its chronic establishment in the human stomach. ${ }^{22,23}$ The vacA gene has a variable structure in two regions: the mid-region, which could be type $\mathrm{m} 1$ (subtype a) or $\mathrm{m} 2$ (subtype a or b); and the other, the second half of the signal sequence, which could be type s1 (subtype a, b and c) or s2. The structure of the $50 \%$ isolated bacteria from the vac $A$ gene is a mosaic with all possible combinations of these two regions, giving rise to different types of alleles. This analysis has allowed an association between the specific $\operatorname{Vac} A$ genotype and the different clinical outcomes. ${ }^{24,25}$

\section{The protein CagA and the cag pathogenicity island}

Equally important is the cytotoxin-associated protein (CagA), present in approximately $80 \%$ of the $\mathrm{H}$. pylori strains. CagA is one of the proteins produced by the cag pathogenicity island (cag PAI). ${ }^{26,27} \mathrm{cag}$ PAI is a DNA segment of approximately $40 \mathrm{~kb}$ that codifies for about 30 proteins. ${ }^{28,29}$ This portion of DNA was probably acquired by horizontal transfer from an unknown source. ${ }^{30}$ Analysis of its genetic sequence has demonstrated that several of its genes encode subunits of the bacterial type IV secretion system (T4SS), which is an extracellular structure in the shape of a tube anchored to the internal membrane of the bacterium and specializes in the transfer of nucleic acids and / or proteins to extracellular space or to the inside of other cells. ${ }^{31} \mathrm{H}$. pylori uses it for the translocation of the CagA protein to the inside of the gastric epithelium cells, where it is phosphorylated in different tyrosine phosphorylation motifs (TPMs). The presence of differences in the TPMs is associated with different degrees of gastric atrophy and the risk of developing gastric cancer. ${ }^{32-34}$ Phosphorylated CagA interferes with various physiological transduction signals in the host cell and causes pathological cellular responses such as increased cellular mobility and massive polymerization of actin, which causes cellular elongation. ${ }^{35}$ The T4SS is also implicated in the transportation of $H$. pylori's peptidoglycan inside the gastric epithelium cells since the elimination of its function significantly reduces the accumulation of this compound, thereby inhibiting the activation of the nuclear transcription factor kappa B (NF-kB) by Nod1 and the secretion of interleukin 8 (IL-8). ${ }^{36}$

\section{The protein HP-NAP}

The Helicobacter pylori neutrophil-activating protein (HP$\mathrm{NAP}$ ) is a multimeric protein of $150 \mathrm{kDa}$ that is present in all strains but with a variable level of expression. HP-NAP exhibits chemiotactic properties for neutrophils and monocytes and contributes substantially to their massive infiltration, high production of reactive oxygen radicals, and adhesion to gastric endothelium cells, which contributes to the chronic inflammation of the gastric mucosa. ${ }^{37,38} \mathrm{HP}-\mathrm{NAP}$ promotes Th1 immune response by increasing the production of IL-12 in monocytes and neutrophiles. ${ }^{39}$ During identification of immunodominant antigens in two-dimensional gels of the H. pylori G27 strain, it was found that this protein is strongly recognized by serum of infected patients with different gastric pathologies. ${ }^{40}$ Also, mice vaccinated with this protein present protection against subsequent infection, which suggests that this virulence factor is an excellent candidate for the development of vaccines. ${ }^{41}$

\section{Development of vaccines}

A large number of animal models, including rodents, ferrets, gnotobiotic pigs, monkeys, dogs and cats have been used to determine the feasibility of development of an effective vaccine against $H$. pylori. The most frequently used animal model has been the murine because it was in these animals that the protective immune response by oral vaccination against Helicobacter felis was demonstrated and because this model has also been particularly successful in assays of $H$. pylori infection that reproduce human infection. ${ }^{42}$ Thus the murine model has allowed the experimentation of prophylactic and therapeutic vaccines containing different antigens, including inactive whole cells, bacterial lysates and various recombinant antigens which, when administered by a mucosal route (oral/intranasal), have resulted in high percentages of protection against infection or curing of the disease. ${ }^{43}$ However, in order for the vaccine antigens to be effective by this route, they must be administered in combination with a mucosal adjuvant that stimulates the immune system and favors the humoral and cellular responses. ${ }^{44,45}$ The mucosal adjuvants most used in mice are cholera toxin (CT) and the thermolabil toxin (LT) of Escherichia coli. However, $\mathrm{CT}$ is too toxic to be given to humans, and the use of LT is also limited because it induces diarrhea. ${ }^{46}$ Nevertheless, the feasibility of inducing therapeutic or prophylactic immune responses against $H$. pylori by vaccination in animal models has stimulated intense research activity to determine whether or not these promising results can be reproduced in humans. Table I summarizes the clinical trials in human volunteers implemented for this purpose. 


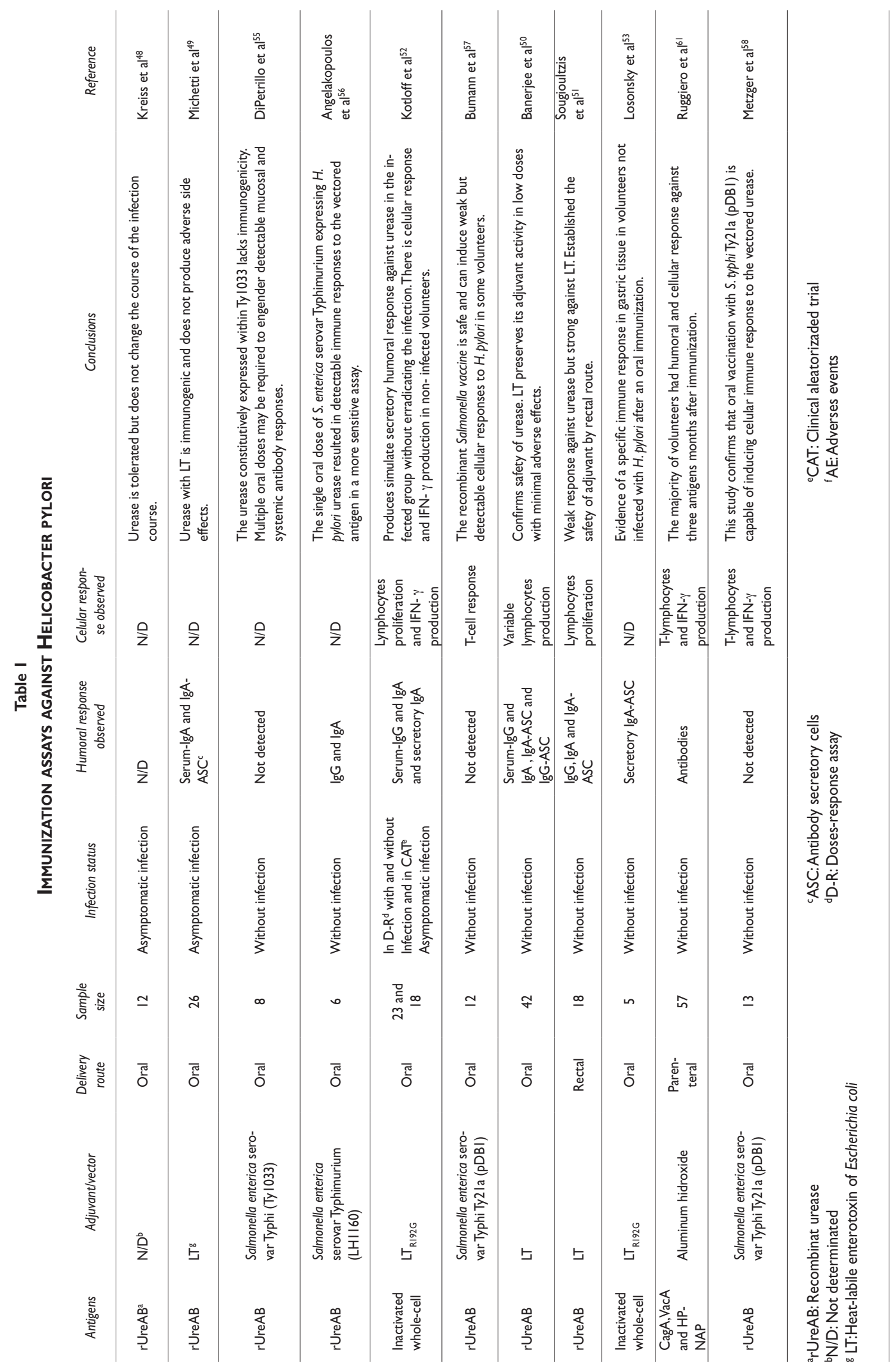




\section{Recombinant UreAB (rUreAB) Vaccine and thermolabil toxin of $E_{\text {. coli (LT) as a }}$ mucosal adjuvant}

Recombinant urease has been shown to produce protective and curative effects against the $H$. felis infection in murine models. However, it also generates an inflammatory process in the gastric corpus after prophylactic immunization. ${ }^{47}$ For this reason, Kreiss and collaborators proposed testing the effect of this protein in a double-blind, random phase one clinical trial on 12 healthy adults with asymptomatic $H$. pylori infection. They demonstrated that the oral administration of the recombinant urease is well tolerated. However, it is not capable of eradicating the infection in the absence of a mucosal adyuvant. ${ }^{48}$ In a second study that was randomized, double-blind and placebo-controlled, Michetti and coworkers tested four weekly oral doses of the urease in combination with the mucosal adjuvant LT in 26 asymptomatic volunteers. This improved vaccine formulation did not eradicate the infection either. However, it induced an increase of antiurease serum IgA titles related to the quantity of administered antigen and a significant decrease in gastric bacterial density (Table I). The only adverse side effect of this vaccine formulation was diarrhea attributed to the heat-labil enterotoxin. However, its incidence and severity decreased with subsequent doses in a pattern consistent with the development of the protective immune response against the adjuvant. ${ }^{49}$ In a third study with the same design as the previous clinical trial, 42 healthy adults received four $60 \mathrm{mg}$ doses of recombinant $H$. pylori urease in soluble or in encapsulated form, given with different quantities of LT ranging from 0 to $2.5 \mu \mathrm{g}$, administered at day 1 , 8,29 , and 57 .

The results of this study demonstrated that LT may retain the mucosal adjuvant properties at a dose of 2.5 $\mu \mathrm{g}$, with minimal side effects. In this formulation, the induction of the humoral and cellular immune responses against the recombinant protein were similar to those observed during their previous study with higher doses of LT. Interestingly, this included activated T lymphocytes and memory cells (Table I). Encapsulated urease, which is acid resistant, may be more capable of inducing lymphocyte response than the soluble form. ${ }^{50}$ Finally, these authors tested the safety and adjuvant efficacy of LT administered in the rectum together with rUreAB in a randomized, double-blind, ascending dose study, in which they administered $60 \mathrm{mg}$ of rUreAB either with 5 or $25 \mu \mathrm{g}$ of LT or without LT in three doses distributed over one month to 18 healthy individuals. The immunization scheme was well tolerated, although it induced a low humoral immune response against the recombinant urease among 12 vaccinated volunteers: two (16.7\%) developed anti-urease IgG antibodies, one $(8.3 \%)$ developed anti-urease IgA antibodies and three (25\%) showed-specific IgA+ antigen secreting cells, while the lymphoproliferation responses were neither uniform nor vigorous. ${ }^{51}$

\section{Vaccine with inactivated $H$. pylori whole- cell and thermolabil toxin $\mathrm{LT}_{\mathrm{R} 192 \mathrm{~g}}$ of $E_{\text {. coli }}$ as a mucosal adjuvant}

The administration of inactivated $H$. pylori whole-cells through the mucosa is another approach that has been explored. Kotloff and collaborators report a vaccine formulation based on chemically inactivated H. pylori whole-cell (HWC) with or without the genetically modified LT variant, $\mathrm{LT}_{\mathrm{R} 192 \mathrm{G}}$ with reduced toxicity as a mucosal adjuvant. Initially, they tested the security and immunogeneity of increasing inocula of HWC, coadministered with $25 \mu \mathrm{g}$ of $\mathrm{LT}_{\mathrm{R}_{192 \mathrm{G}}}$ in a dose-response study of 23 volunteers with or without infection. Afterwards, a randomized, double-blind, placebo-controlled study was conducted in a new group in which $18 \mathrm{H}$. pyloriinfected volunteers received in three doses one of the following combinations: $2.5 \times 10^{10} \mathrm{HWC}$ plus placeboadjuvant; placebo-vaccine plus $25 \mu \mathrm{g}$ of LTR192G; placebo-vaccine plus placebo-adjuvant; or $2.5 \times 10^{10}$ HWC plus $25 \mu \mathrm{g}$ of $\mathrm{LT}_{\mathrm{R} 192 \mathrm{G}}$. Although there was no evidence that vaccination with inactivated $\mathrm{HWC}$ is capable of eradicating $H$. pylori infection, both the infected and uninfected volunteers presented significant rises in mucosal (fecal and salivary) anti-HWC IgA antibodies after being inoculated with $2.5 \times 10^{10} \mathrm{HWC}$ plus $25 \mu \mathrm{g}$ of $\mathrm{LT}_{\mathrm{R} 192 \mathrm{G}}$. Furthermore, in the majority of the non-infected individuals, there was an increase in gamma interferon (IFN- $\gamma$ ) production and lymphoprolipherative response. It was also observed that adverse effects of the immunization were attributed to the toxicity of $\mathrm{LT}_{\mathrm{R} 192 \mathrm{G}}{ }^{52} \mathrm{In}$ a later study, the same vaccine formulation was administered in three doses to five non-infected volunteers. Two of these individuals presented detectable $\mathrm{LT}_{\mathrm{R} 192 \mathrm{G}}$ and HWC IgA antibody secretion cell gastric responses, with the duodenal response greater than that of the antrum (Table I). This is the first evidence of this type of response in the mucosa of healthy individuals after an oral immunization. ${ }^{53}$

\section{Vaccines with rUreAB with attenuated live vectors as adjuvants}

The oral administration of attenuated bacteria of the genus Salmonella represents an appealing option to be used as live bacterial vectors for the delivery of heterologous 
antigens. ${ }^{54}$ Thus some research groups have explored this form of immunization as an alternative to prevent $H$. pylori infection. The first evaluation of the safety and immunogeneity of rUreAB of $H$. pylori using the Ty 800 strain of Salmonella enterica serovar Typhi attenuated by the elimination of the $\mathrm{phoP} / \mathrm{phoQ}$ regulon genes was carried out by DiPetrillo and collaborators. ${ }^{55}$ They engineered this Salmonella strain to constitutively express the subunits $\mathrm{A}$ and $\mathrm{B}$ of $\mathrm{H}$. pylori urease to obtain the strain Ty1033. Later they administered a single oral dose of this strain at a concentration of $\geq 10^{10}$ colony-forming units (CFU) in seven healthy volunteers, while an eighth received two doses three months apart. Two of the eight volunteers experienced diarrhea as a side effect, which was attributed to the live bacterial vector. All of the volunteers developed strong serological and mucosal immune responses to the $S$. thyphi antigens, but none of them developed any of these responses to the vectored urease, including the three volunteers who received an oral booster vaccination with recombinant UreAB and LT two weeks after the first oral immunization. In an attempt to further define the variable for engendering immune responses to vectored antigens in humans, Angelakopoulos and collaborators carried out another study using an attenuated strain of S. enterica serovar Typhimurium ( $p h o P / p h o Q$ regulon deleted) that constitutively expressed UreAB.

Six volunteers were vaccinated profilactically with $5-8 \times 10^{7} \mathrm{CFU}$ of this strain. Two of them presented fever without other serious side effects, while five presented antibodies against the vector. In this case, the analysis of the vaccine-specific $\operatorname{IgA}$ and $\operatorname{IgG}$ release by high-density cultured peripheral mononuclear blood cells into culture medium was used as a more sensitive assay for immunoglobulines detection, which allowed observation of detectable immune responses to urease in $50 \%$ of the inoculated subjects. ${ }^{56}$ Two years later, another group carried out a clinical test with twelve healthy volunteers. Nine received the common live typhoid fever vaccine Salmonella enterica serovar Typhi Ty21a that constitutively expressed UreAB, Ty21a (pDB1), and three received only the Salmonella Ty21a strain in three doses of 6, 7 and $9 \times 10^{9}$ bacteria each. In $83 \%$ (10/12) of the volunteers, a humoral and cellular immune response was detected against the vector, while only $33 \%$ (3/9) of the vaccinated volunteers presented a weak but detectable cellular response to urease, and 22\% (2/9) showed a cellular response of IFN-y production and no detectable humoral response. This suggests that this type of vaccination could be adapted to induce efficient protection against the $H$. pylori infection. The patients who presented a cellular response against the urease had been previously immunized with Ty21a. ${ }^{57}$ To evaluate whether preexisting immunogeneity to the vector increases the response to the recombinant antigen, these authors designed a second clinical test in which 13 volunteers previously vaccinated with Salmonella received a treatment of three doses of $1-2 \times 10^{10}$ live bacteria. Four received the $S$. typhi Ty21a strain and the other nine received the Ty21a (pDB1) vaccine that expresses the urease subunits. This study showed that the majority $(5 / 9)$ of the volunteers immunized with the Ty21a (pDB1) vaccine presented a cellular immune response against the urease, similar to the previous study (Table I). Finally, the authors concluded that prevaccination does not increase the response ranges to the recombinant protein or the secondary effects induced by the vector. ${ }^{58}$

\section{Vaccines with VacA, CagA and HP-NAP through parenteral administration}

Parenteral vaccination has been shown to provide good protection in animal models against $H$. pylori infection. However, in the majority of the cases, the vaccines tested consisted of bacterial lysates instead of well-defined recombinant proteins. The first tests were based on the vaccination model against pertussis and showed that effective immunity is achieved through the combination of participant antigens in different aspects of the infection's pathogenesis. ${ }^{59}$ Thus a multicomponent intramuscular vaccine was developed based on the recombinant proteins VacA, CagA and HP-NAP, using aluminum hydroxide as an adjuvant. These studies reported, in a preliminary way, that the vaccine did not show adverse effects in humans and induced the production of antibodies and cellular responses against the three antigens in the majority of the 57 participants at a detectable level for several months (Table I). This demonstrated the immunoreactivity and safety of this vaccine. However, published results that demonstrate the effectiveness of this vaccine against colonization are still pending. ${ }^{60,61}$

\section{Discussion}

The administration of vaccines is an effective method to prevent morbidity and mortality caused by infectious diseases. H. pylori is associated with various gastroduodenal diseases and the different strains present a growing resistance to antibiotics all over the world. Thus the development of a vaccine is an alternative strategy for the treatment and control of this infection.

However, $H$. pylori studies carried out to determine the best vaccination method to induce said response are few, and their determination methodologies vary. Thus it is difficult to compare results obtained to date. (Table I). Nevertheless, these studies have established a 
foundation for the development of an effective vaccine against this infection.

The first study using urease as an orally administered antigen indicated the need to use adjuvants that could induce a more efficient immune response, as with the murine model. Therefore, later studies focused on testing various adjuvants as well as vectors to stimulate a better immune response against the antigen used. However, the response was always very low compared to the adjuvant or vector. Nevertheless, these studies demonstrated the possibility of inducing a humoral response in mucosas and stimulation of T-lymphocytes and memory cells in humans.

It is not clear what type of immune response is capable of eliminating the bacterium. This would be the most important step in defining whether the ideal vaccine should be therapeutic or prophylactic. Knowledge obtained to date suggests that because of the high prevalence and early age at which the infection is acquired, testing should continue to be carried out for both alternatives. To date, the multicomponent vaccine using parenteral administration has provided the best result. However, we must not forget that this is a phase one test that cannot be considered successful until it passes the subsequent phases and is proven at the populational level. Thus, it is probable that with a greater number of studies in this direction, it will finally be possible to control the infection and decrease the clinical manifestations associated with $H$. pylori through vaccination.

\section{Acknowledgments}

This work was supported by CONACYT grants 37181-B and V51136-M.

\section{References}

I.Warren JR, Marshall B. Unidentified curved bacilli on gastric epithelium in active chronic gastritis. Lancet 1983; I: I273-1275.

2. Marshall BJ, Royce H,Annear DI, Goodwin CS, Pearman JW, Warren JR, Amstrong JA. Original isolation of Campylobacter pyloridis from human gastric mucosa. Microbios Lett 1984;25:83-88.

3.Woodward M, Morrison C, McColl K.An investigation into factors associated with Helicobacter pylori infection.J Clin Epidemiol 2000; 53(2): 175-18I.

4. Lambert JR, Lin SK, Sievert W, Nicholson L, Schembri M, Guest C. High prevalence of Helicobacter pylori antibodies in an institutionalized population: evidence for person-to-person transmission. Am J Gastroenterol 1995;90;12:2167-2171.

5. Malaty HM, Graham DY, Klein PD, Evans DG,Adam E, Evans DJ. Transmission of Helicobacter pylori infection. Studies in families of healthy individuals. Scand J Gastroenterol I991;26:927-932.

6. Dowsett, SA, Archila L, Segreto VA, Gonzalez CR, Silva A.,Vastola KA, et al. Helicobacter pylori infection in indigenous families of Central America:
Serostatus, oral and fingernail carriage.J Clin Microbiol 1999;37(8): 2456-2460.

7. Mazari-Hiriart M, Lopez-VidalY, Calva JJ. Helicobacter pylori water systems for humans use in Mexico City.Water Sci and Technol 200 I; 43:93-98. 8. Mazari-Hiriart M, Lopez-VidalY, Ponce de Leon S, Castillo-Rojas G, Hernandez-Eugenio C, Rojo F. Bacteria and disinfection by products in water from southern Mexico City.Arch Environ Health 2003; 58:233-237. 9. Kelly SM, Pitcher MC, Farmery SM, Gibson GR. Isolation of Helicobacter pylori from feces of patients with dyspepsia in the United Kingdom.

Gastroenterology 1994;107(6): 167|-1674.

10. Portal-Celhay C, Pérez-Pérez GI. Immune responses to Helicobacter pylori colonization: mechanisms and clinical outcomes. Clinical Science 2006; II0: 305-314.

I I. Parsonnet J, Friedman GD, Vandersteen DP, Chang Y,Vogelman JH, Orentreich $\mathrm{N}$, et al. Helicobacter pylori infection and the risk of gastric adenocarcinoma. N Engl J Med |99|; 325: | |27- | |3|.

12. Parsonnet J, Hansen S, Rodriguez L, Gelb AB, Warnke RA, Jellum E, et al. Helicobacter pylori and gastric lymphoma. N Engl J Med 1994; 330:1267-1271.

13. Blaser MJ. Hypothesis: the changing relationships of Helicobacter pylori and humans: implications for health and disease.J Infect Dis 1999; 179(6): 1523-1530.

14. Moxon R, Rappouli R, Bacterial pathogen genomics and vaccines. British Med Bulletin 2002; 62: 45-48.

15. Suerbaum S, Josenhans C.Virulence factors of Helicobacter pylori: implications for vaccine development. Mol Med Today 1999; 5:32-39. 16. Michetti P,Svennerholm AM, Helicobacter pylori-Inflamation, Immunity and vaccines. Helicobacter 2003; 8 (suppl I):3I-35.

17. Meyer-Rosberg K, Scott DR, Rex D, Melchers K, Sachs G. The effect of environmental $\mathrm{pH}$ on the proton motive force of Helicobacter pylori. Gastroenterology 1996; I I :886-900.

18. Tsuda M, Karita M, Morshed MG, Okita K, Nakazawa T.A ureasenegative mutant of Helicobacter pylori constructed by allelic exchange mutagenesis lacks the ability to colonize the nude mouse stomach. Infect Immun 1994; 62:3586-3589.

19. Czajkowsky DM, Iwamoto H, Cover TL, Shao Z. The vacuolating toxin from Helicobacter pylori forms hexameric pores in lipid bilayers at low $\mathrm{pH}$. Proc Natl Acad Sci USA 1999;96(5):200I-2006.

20.Atherton JC, Peek RM, Tham KT, Cover TL, Blaser MJ. Clinical and pathological importance of heterogeneity in vacA, the vacuolating cytotoxin gene of Helicobacter pylori. Gastroenterology 1997; I 12: 92-99. 21. Molinari M, Galli C, Norais N, Telford JL, Rappuoli R, Luzio JP, et al. Vacuoles induced by Helicobacter pylori toxin contain both late endosomal and lysosomal markers.J Biol Chem 1997; 272:25339-25344.

22. Molinari M, Salio M, Galli C, Norais N, Rappuoli R, Lanzavecchia A, et al. Selective inhibition of li-dependent antigen presentation by Helicobacter pylori toxin VacA.J Exp Med 1998; 187:135-140.

23. Reyrat JM, Pelicic V, Papini E, Montecucco C, Rappuoli R, Telford JL.

Towards deciphering the Helicobacter pylori cytotoxin. Mol Microbiol 1999; 34:197-204.

24. Atherton JC, Cao P, Peek RM Jr, Tummuru MK, Blaser MJ, Cover TL. Mosaicism in vacuolating cytotoxin alleles of Helicobacter pylori. Association of specific vacA types with cytotoxin production and peptic ulceration.J Biol Chem I 995 Jul 28;270(30): I777I-I 7777.

25. Van Doorn LJ, Figueiredo C, Sanna R, Pena S, Midolo P, Enders KWNG et al. Expanding allelic diversity of Helicobacter pylori vacA.J Clin Microbiol 1998 Sep;36(9):2597-2603.

26. Akopyants NS, Clifton SW, Kersulyte D, Crabtree JE, Youree BE, Reece $\mathrm{CA}$, et al. Analyses of the cag pathogenicity island of Helicobacter pylori. Mol Microbiol 1998 Apr;28(I):37-53.

27. Censini S, Lange C, Xiang Z, Crabtree JE, Ghiara P, Borodovsky M, et al. cag, a pathogenicity island of Helicobacter pylori, encodes type 
I-specific and disease-associated virulence factors. Proc Natl Acad Sci USA 1996; 10;93(25): | 4648-14653.

28. Tomb JF, White O, Kerlavage AR, Clayton RA, Sutton GG, Fleischmann $\mathrm{RD}$, et al. The complete genome sequence of the gastric pathogen Helicobacter pylori. Nature 1997;388(6642):539-547.

29. Alm RA, Ling LS, Moir DT, King BL, Brown ED, Doig PC, et al. Genomicsequence comparison of two unrelated isolates of the human gastric pathogen Helicobacter pylori. Nature 1999;397(6715): 176-180.

30. Marshall DG, Dundon WG, Beesley SM, Smyth CJ. Helicobacter pylori a conundrum of genetic diversity. Microbiology 1998; 144 (Pt II): 2925-2939.

3I. Backert S, Meyer TF. Type IV secretion systems and their effectors in bacterial pathogenesis. Curr Opin Microbiol 2006;9(2):207-2I7. 32. Yamaoka Y, Kodama T, Kashima K, Graham DY, Sepulveda AR.Variants of the 3'region of the cagA gene in Helicobacter pylori isolates from patients with different $H$. pylori-associated diseases.J Clin Microbiol 1998; 36:2258-2263.

33. Selbach M, Moese S, Hauck CR, Meyer TF, Backert S. Src is the kinase of the Helicobacter pylori CagA protein in vitro and in vivo.J Biol Chem 2002; 277:6775-6778.

34. Stein M, Bagnoli F, Halenbeck R, Rappuoli R, Fantl WJ, Covacci A. c-Src/Lyn kinases activate Helicobacter pylori CagA through tyrosine phosphorylation of the EPIYA motifs. Mol Microbial 2002; 43:97I-980. 35. Tsutsumi R, Takahashi A, Azuma T, Higashi H, Hatakeyama M. Focal adhesion kinase is a substrate and downstream effector of SHP-2 complexed with Helicobacter pylori CagA. Mol Cell Biol 2006;26(I): 261-276.

36.Viala J, Chaput C, Boneca IG, Cardona A, Girardin SE, Moran AP, et al. NodI responds to peptidoglycan delivered by the Helicobacter pylori cag pathogenicity island. Nat Immunol 2004;5(I I): I099-I I00.

37. Dundon WG; Nishioka H; Polenghi A; Papinutto E; Zanotte G, Montemurro P. et al. The neutrophil-activating protein of Helicobacter pylori. Int J Med Microbiol 2002; 291: 545-550.

38. Polenghi A, Bossi F, Fischetti F,Durigutto P, Cabrelle A, Tamassia N, et al.The neutrophil-activating protein of Helicobacter pylori crosses endothelia to promote neutrophil adhesion in vivo. The J of Immun 2007; |78:13/2-1320.

39. Amedei A, Cappon A, Codolo G, Cabrelle A, Polenghi A, Benagiano M,et al. The neutrophil-activating protein of Helicobacter pylori promotesTh I immune responses J Clin Invest 2006; I I6: 1092-I I0I.

40. Kimmel B, Bosserhoff A, Frank R, Gross R, Goebel W, Beier D. Identification of immunodominant antigens from Helicobacter pylori and evaluation of their reactivities with sera from patients with different gastroduodenal pathologies. Infect Immun 2000; 68:915-920. 4I. Satin B, Del Giudice G, Della Bianca V, Dusi S, Laudanna C, Tonello F, et al. The neutrophil-activating protein (HP-HP-NAP) of Helicobacter pylori is a protective antigen and a major virulence factor.J Exp Med 2000;| |9|(9): | 467-| 476.

42. Marchetti M,Arico B, Burroni D, Figura N, Rappuoli R, Ghiara P. Development of a mouse model of Helicobacter pylori infection that mimics human disease. Science 1995;267(5204): 1655-1658. 43. Harris P, Serrano C,Venegas A.Vacunas en desarrollo: Helicobacter pylori. Rev Chil Infectol 2006;23(3):249-256.

44. Del Giudice G, Covacci A, Telford JL, Montecucco C, Rappuoli R. The design of vaccines against Helicobacter pylori and their development. Annu Rev Immunol 200I;19:523-563.
45. Aguilar JC, Rodríguez EG.Vaccine adjuvants revisited.Vaccine 2007;25:3752-3762

46. Pizza M, Giuliani MM, Fontana MR, Monaci E, Douce G, Dougan G, et al. Mucosal vaccines: non toxic derivatives of $L T$ and $C T$ as mucosal adjuvants. Vaccine 200I;19(I7-19):2534-254I.

47. Michetti P, Corthésy- Theulaz I, Davin C, Hass R, Vaney AC, Heitz M, et al. Immunization of BALB/c mice against Helicobacter felis infection with $\mathrm{H}$. pylori urease.Gastroenterology 1994; 107:1002-101 I.

48. Kreiss C, Buclin T, Cosma M, Corthesy-Theulaz I, Michetti P. Safety of oral immunisation with recombinant urease in patients with Helicobacter pylori infection. Lancet 1996;347(9015): 1630-1631.

49. Michetti P, Kreiss C, Kotloff KL, Porta N, Blanco JL, Bachmann D, Herranz M, et al. Oral immunization with urease and Escherichia coli heatlabile enterotoxin is safe and immunogenic in Helicobacter pylori-infected adults. Gastroenterology 1999; I I6(4):804-8I2.

50. Banerjee S, Medina-Fatimi A, Nichols R, Tendler D, Michetti M, Simon J, et al. Safety and efficacy of low dose Escherichia coli enterotoxin adjuvant for urease based oral immunisation against Helicobacter pylori in healthy volunteers. Gut 2002;5 I(5):634-640.

5I. Sougioultzis S, Lee CK, Alsahli M, Banerjee S, Cadoz M, Schrader R, et al. Safety and efficacy of $E$ coli enterotoxin adjuvant for urease-based rectal immunization against Helicobacter pylori. Vaccine 2002;2I(3-4): 194-20I.

52. Kotloff KL, Sztein MB,Wasserman SS, Losonsky GA, DiLorenzo SC, Walker RI. Safety and immunogenicity of oral inactivated whole-cell Helicobacter pylori vaccine with adjuvant among volunteers with or without subclinical infection. Infect Immun 200I;69(6):358I-3590. 53. Losonsky GA, Kotloff KL,Walker RI. B cell responses in gastric antrum and duodenum following oral inactivated Helicobacter pylori whole cell (HWC) vaccine and $L T(R / 92 G)$ in $H$. pylori seronegative individuals. Vaccine 2003;2I (5-6):562-565.

54. Cheminay C, Hensel M. Rational design of Salmonella recombinant vaccines. Int J Med Microbiol 2008;298(I-2):87-98.

55. DiPetrillo MD, Tibbetts T, Kleanthous H, Killeen KP, Hohmann EL. Safety and immunogenicity of phoP/phoQ-deleted Salmonella typhi expressing Helicobacter pylori urease in adult volunteers. Vaccine 2000; 18(5-6):449-459.

56. Angelakopoulos $\mathrm{H}$, Hohmann EL. Pilot study of phoP/phoQ-deleted Salmonella enterica serovar typhimurium expressing Helicobacter pylori urease in adult volunteers. Infect Immun 2000;68(4):2 I35-2 I4I.

57. Bumann D, Metzger WG, Mansouri E, Palme O,Wendland M, Hurwitz $\mathrm{R}$, et al. Safety and immunogenicity of live recombinant Salmonella enterica serovar Typhi Ty 2 la expressing urease $A$ and $B$ from Helicobacter pylori in human volunteers. Vaccine 2001;20(5-6):845-852.

58. Metzger WG, Mansouri E, Kronawitter M, Diescher S, Soerensen M, Hurwitz R, et al. Impact of vector-priming on the immunogenicity of a live recombinant Salmonella enterica serovar typhi Ty2 la vaccine expressing urease $A$ and $B$ from Helicobacter pylori in human volunteers. Vaccine 2004:22(I7- |8):2273-2277.

59. Commite of infectious diseases. Acellullar pertussis vaccine. Recomendations for use as the initial series in infants and children. Pediatrics 1997; 99:282-288.

60. Malfertheiner P, Schultze V, Del Giudice G, Rosenkranz B, Kaufmann $\mathrm{SH}$,Winau F, et al. Phase I safety and immunogenicity of a threecomponent $H$. pylori vaccine. Gastroenterology 2002; 122 (suppl A-585): Abstr.WII95.

6I. Ruggiero P, Peppoloni S, Rappuoli R, Del Giudice G. The quest for a vaccine against Helicobacter pylori: how to move from mouse to man? Microbes Infect 2003;5(8):749-756. 